\title{
Induced pluripotent stem cells reprogramming: Epigenetics and applications in the regenerative medicine
} \author{
Maria Fernanda Forni ${ }^{4}$, Julio Cesar Batista Ferreira ${ }^{1}$

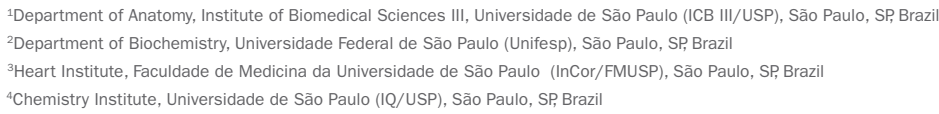

Kátia Maria Sampaio Gomes ${ }^{1 *}$, Ismael Cabral Costa ${ }^{1}$, Jeniffer Farias dos Santos ${ }^{2}$, Paulo Magno Martins Dourado ${ }^{3}$,

Study conducted at Universidade de São Paulo (USP), São Paulo, SP, Brazil

Article received: $5 / 23 / 2016$ Accepted for publication: 5/30/2016

*Correspondence: Departamento de Anatomia, ICB III/USP Address: Av. Prof. Lineu Prestes, 2415, Cidade Universitária São Paulo, SP - Brazi Postal code: 05508-000 kmsgomes@gmail.com

http://dx.doi.org/10.1590/1806-9282.63.02.180

\section{SUMmARY}

Induced pluripotent stem cells (iPSCs) are somatic cells reprogrammed into an embryonic-like pluripotent state by the expression of specific transcription factors. iPSC technology is expected to revolutionize regenerative medicine in the near future. Despite the fact that these cells have the capacity to self-renew, they present low efficiency of reprogramming. Recent studies have demonstrated that the previous somatic epigenetic signature is a limiting factor in iPSC performance. Indeed, the process of effective reprogramming involves a complete remodeling of the existing somatic epigenetic memory, followed by the establishment of a "new epigenetic signature" that complies with the new type of cell to be differentiated. Therefore, further investigations of epigenetic modifications associated with iPSC reprogramming are required in an attempt to improve their self-renew capacity and potency, as well as their application in regenerative medicine, with a new strategy to reduce the damage in degenerative diseases. Our review aimed to summarize the most recent findings on epigenetics and iPSC, focusing on DNA methylation, histone modifications and microRNAs, highlighting their potential in translating cell therapy into clinics.

Keywords: induced pluripotent stem cells, regenerative medicine, cell reprogramming, epigenetics, histones, microRNAs.

\section{INTRODUCTION}

Human embryonic stem cells have great potential for self-renewal and the ability to differentiate into all tissues of the body (except embryonic attachments), ${ }^{1}$ forming an important source of material for regenerative medicine and cell therapy. However, the use of embryonic stem cells is limited by ethical and religious conflicts, as well as immunological incompatibility. ${ }^{2}$ In order to reduce the damage caused by degenerative diseases, different strategies are being used in an attempt to optimize the use of embryonic stem cells.

The first strategy used was that of somatic cell nuclear content (SCNT) for unfertilized and enucleated oocytes. ${ }^{3}$ However, the yield of this technique is still very low and the cells obtained can present phenotypic and gene expression abnormalities. ${ }^{4}$ Another strategy is the fusion of somatic cells with embryonic cells, reprogramming their genome. ${ }^{5}$ However, although fusion-induced reprogramming is very efficient (about $95 \%$ ), the resulting hybrid cells lack therapeutic potential due to their tetraploidy, as well as the presence of exogenous genes from the pluripotent cells used in the fusion. ${ }^{5}$ Therefore, a search for new strategies for the efficient use of cells with an embryonic profile is still needed.

In 2006 Takahashi and Yamanaka managed to induce pluripotency in mouse fibroblasts (MEF) from the expression of four embryonic transcription factors (Oct4, Sox2, Klf4, c-Myc), currently known as OSKM or "Yamanaka factors." These cells were called induced pluripotent stem cells (iPSCs). ${ }^{6}$ The iPSC are similar to embryonic cells in terms of morphology, gene expression, differentiation status and epigenetic pattern, both in culture, as well as in vivo. ${ }^{7}$ This mechanism of reprogramming somatic cells into embryonic stem cells resulted in the Nobel Prize in 
medicine for Yamanaka in 2012, shared with John b. Gurdon. ${ }^{8}$ Since then, several surveys have been developed to explore this technology. In fact, several researchers were able to reprogram somatic cells (postmitotic) into iPSC using the aforementioned strategy. ${ }^{9-11}$

The advantage of using this method is that it allows the derivation of pluripotent cells from the donor, reducing the risk of rejection by the immune system. In addition, this method provides a platform to study the molecular mechanisms of genetic and chronic diseases, minimizing the ethical, religious and political conflicts and opening up new perspectives for regenerative medicine. However, although cell identity can be modified by the ectopic expression of transcription factors, the efficiency of reprogramming remains low $(0.1$ to $3 \%)$ and its cost is high. ${ }^{11,12}$

The low reprogramming efficiency of iPSC is associated with residual epigenetic memory of the tissue from which they were derived, which complicates the reprogramming process. Recent studies show that despite iPSC sharing common characteristics of pluripotency and self-renewal capacity, these cells still retain an epigenetic memory. ${ }^{13-15}$ In addition, there is evidence that the reprogramming process involves complete remodeling of the existing somatic epigenetic memory, followed by the establishment of a new "epigenetic signature" that conforms to the type of cell to be differentiated. ${ }^{16}$ Therefore, the epigenetic memory becomes a barrier in the process of cellular reprogramming. This fact highlights the need for new studies investigating the epigenetic changes associated with cellular reprogramming in an attempt to improve the efficiency and effectiveness of the iPSC created, as well as their clinical application. As such, our review aimed to gather information about the epigenetic factors (DNA methylation, changes to histones and microRNAs) associated with iPSC reprogramming efficiency. In addition, we have brought together the clinical studies using iPSC as cell therapy.

\section{EPIGENETICS AND IPSC}

Waddington was the first researcher to use the term epigenetics in 1942 to explain how the genome interacts with the environment during the development process. ${ }^{17}$ Therefore, any reversible and inheritable change in the functional genome that does not alter the sequence of DNA nucleotides refers to epigenetics. ${ }^{18}$ Several pathologies are associated with epigenetic changes. ${ }^{19-22}$

The reprogramming efficiency of iPSC is also directly related to epigenetic changes such as DNA methylation and the epigenetic memory of the source cells. ${ }^{23}$ The iPSC reprogramming process can be divided into three distinct phases, called pre-iPSC, intermediate and full reprogramming. The reprogramming process is extremely slow, with low efficiency (0.1 to $3 \%$ ) and high cost, ${ }^{11,12}$ and depends on suitable levels of gene expression in each phase and specific epigenetic changes. ${ }^{24}$ Djuric and Ellis compared the epigenetic changes that occur during the reprogramming process with a "seven headed dragon," where a series of changes is necessary for efficient reprogramming, namely: 1) Endogenous reactivation of genes related to cell pluripotency, Nanog and Oct4; 2) Chromatin changes, such as trimethylation in $\mathrm{H} 3 \mathrm{~K} 27$ and changes in H3K4; 3) Hypomethylation of heterochromatin; 4) Reactivation of the inactive X chromosome; 5) Maintenance of DNA methylation marks; 6) Silencing the retrovirus that induces pluripotency; and, finally, 7) Two- or three-dimensional chromatin changes and location of nuclear subdomains. ${ }^{24}$ Therefore, the control of epigenetic factors during reprogramming may improve the induction of iPSC and their efficiency. ${ }^{25}$

\section{EPIGENETIC CHANGES IN IPSC REPROGRAMMING \\ DNA methylation in IPSC reprogramming}

DNA methylation is an epigenetic mechanism involved in many important cellular processes such as cell proliferation and differentiation, transcriptional repression, genomic imprinting, organization of chromatin and inactivation of the $\mathrm{X}$ chromosome. ${ }^{26}$ Thus, changes in the DNA methylation profile are associated with the appearance of many degenerative diseases.

Studies show that DNA methylation is considered a crucial epigenetic barrier in the reprogramming of iPSC. .7-31 $^{2}$ For the expression of genes essential for reprogramming, such as Oct3/4 and Nanog, demethylation of cytosines is necessary in the respective promoter regions. ${ }^{32}$ Thus, inhibition of methylation by enzymes or interfering RNA may be an option to improve this process. ${ }^{33}$ Mikkelsen et al. showed that the use of 5-azacytidine (AZA) inhibits the enzyme DNA methyltransferase 1, assisting in DNA demethylation, which may favor the reprogramming of iPSC. ${ }^{33}$ Another study noted an improvement in reprogramming efficiency using DNA hydroxylase (Tet1), an enzyme that is able to oxidize 5-methylcytosine and, after subsequent replications, promotes DNA demethylation by reactivating Oct 4 gene transcription, favoring the reprogramming process. ${ }^{31}$ In addition to the use of AZA and the enzyme Tet1, other researchers have used ascorbic acid (vitamin C). Vitamin C acts as a cofactor, stimulating hypomethylation and consequently increasing the activity of histone $\mathrm{H} 3 \mathrm{~K} 36$ demethylase. This process results in an improvement of cellular reprogramming efficiency. ${ }^{34-36}$ 
The aforementioned studies demonstrate the importance of DNA demethylation in cell reprogramming. Several studies have attempted to improve these and other epigenetic mechanisms in order to improve both the quality and efficiency of iPSC reprogramming. Another relevant topic for such improvement is the change in histones during the reprogramming process.

\section{Changes to histones in iPSC reprogramming}

Histones are basic proteins rich in lysine and may suffer several epigenetic changes. Most of these modifications happen in the $\mathrm{N}$-terminal region of the histone, with the exception of ubiquitination, which occurs in the C-terminal region of $\mathrm{H} 2 \mathrm{~A}$ and $\mathrm{H} 2 \mathrm{~B} .{ }^{37}$ Epigenetic modifications to histones may either promote or inhibit gene transcription by changing the level of chromatin folding. ${ }^{38,39}$

Taking into consideration the epigenetic changes in histones in $\mathrm{PSC}, \mathrm{H} 3$ is the histone researched the most, as it is directly related to genes expressed during embryonic development, such as Oct3/4, Sox 2 and Nanog. It has already been demonstrated that methylation of H3K27 is associated with the suppression of various genes, and that persistent trimethylation of the lysine 27 of histone 3 (H3K27me3) blocks reprogramming by repressing the chromatin region associated with the target genes of the stem cells. However, the methylation of H3K4 is associated with the activation of different embryonic genes. ${ }^{24}$ In an attempt to improve the performance of iPSC and reach the ideal conditions for the induction of pluripotency, by reducing the "epigenetic memory" in somatic cells, different strategies that directly or indirectly affect the methylation/acetylation of $\mathrm{H} 3$ have been used. ${ }^{12} \mathrm{Sev}-$ eral researchers have demonstrated that it is possible to perform the induction of pluripotency without the use of Yamanaka factors, using only chemical compounds/ molecules that interfere with the enzymes that control the chromatin structure. ${ }^{40}$

Recently, Rais et al. showed that the inhibition of Mbd3 - a subunit of the NuRD complex responsible for the deacetylation of histones, remodeling of nucleosomes and gene expression inhibition - is able to reactivate the genes expressed during embryonic development and improve the efficiency of iPSC reprogramming by almost $90 \%$, both in human as well as mouse cells. ${ }^{41}$

Many other strategies have been tested in order to improve the iPSC reprogramming process, such as the use of small molecules like Forskolin (FSK), ${ }^{42}$ BIX-01294, ${ }^{43}$ valproic acid (VPA - HDAC histone deacetylase inhibitor) ${ }^{44}$ and vitamin $\mathrm{C} .{ }^{45}$ Therefore, the induction of pluripotency of iPSC can only occur with the use of small mol- ecules. ${ }^{46-48}$ The authors advocate the use of such because they are not immunogenic, with greater yield and easy production. Thus, the use of chromatin modulators can increase efficiency in the iPSC reprogramming process. ${ }^{49}$ To do so, it is necessary to use a small molecule that is able to demethylate the DNA in the promoter region and change specific regions in histones.

\section{MicroRNAs in iPSC reprogramming}

MicroRNA or miRNA are important tools for regulating gene expression in post-transcriptional iPSC by promoting pluripotency to modulate the stability of messenger RNA (mRNA) and suppress the signs of differentiation during the self-renewal of embryonic stem cells.

MiRNAs also modulate the signaling cascades that are necessary for maintaining the pluripotent state. ${ }^{50}$ Wang et al. noted that the loss of function in the enzyme Dicer and DGCR8, proteins essential for the biogenesis of microRNAs in the embryonic stem cells of mice, present two different phenotypes: 1 ) reduction in proliferation due to cell cycle arrest in G1; and 2) resistance to differentiation, which reveals a close relationship between microRNAs, differentiation and the pluripotency of cells. ${ }^{51,52}$

MicroRNAs are small non-coding RNA molecules. They have 18-25 nucleotides (nt), and are derived from a larger precursor. The processing of microRNAs occurs as follows:

1. After DNA transcription by RNA polymerase II or III the primary microRNA is formed (pri-miRNA). This may be presented in the shape of a fork. The pri-miRNA first undergoes processing by the enzyme ribonuclease (RNase) nuclear III-like DROSHA. The specificity of the cleavage in this step is guided by the DGCR8 protein, which acts as a "molecular ruler," positioning the DROSHA at a distance of 11 nucleotides from the base of the pri-miRNA loop. After cleavage, a premiRNA (precursor miRNA) is released, formed by about 60-70 nt. ${ }^{53}$

2. The pre-miRNA is actively transported to the cytoplasm by exportin-5 (Exp5), when this protein is linked to its Ran-dependent GTP cofactor. In the cytoplasm, it undergoes another cleavage process, where it loses the loop and is reduced to a miRNA duplex approximately $18-25 \mathrm{pb}$ in length. This last stage of processing is conducted by DICER, an RNAse-III type enzyme, aided by the TRBP protein. ${ }^{53}$

3. Finally, the RNA-binding protein TRBP recruits a multimeric complex denominated RISC (RNA-induced silence complex), which includes the protein Argonaute 2 (in mammals) as the main component. 
Only one of the microRNA duplex strands remains in the RISC complex (guide strand), with the other being degraded (passenger strand). The RISC complex is able to identify and bind to target messengers RNAs in region 3'UTR through complementarity of bases in the "SEED" region of the miRNA (nucleotides 2-8 from the 5' end) in order to inhibit its translation or promote its adenylation and degradation..$^{53}$

\section{MicroRNAs that promote the reprogramming of iPSC}

- miR 290-295 (cluster): These constitute more than $70 \%$ of the entire population of microRNAs in the embryonic stem cells of mice. miR 291-3 p, miR-294 and miR-295 are part of this cluster and indirectly promote the transition of genes associated with entry into the G1-S phase, blocking Cdkna (p21), a suppressor of the Cyclin $\mathrm{E} / \mathrm{Cdk} 2$ complex, and regulator of the cell cycle. After its transfection into MEFs there is an increase of $0.01-0.05 \%$ to $0.1-0.3 \%$ in cell reprogramming efficiency. ${ }^{54}$

- $\quad$ miR 302-367 and miR 371-373 (cluster): These miRNAs suppress the expression of MBD2 (methyl-CPG-binding domain protein 2), which works like a demethylase in cells, resulting in increased expression of Nanog and conversion of completely reprogrammed iPSC. They are also able to reduce expression of the inhibitors in the G1-S phase, as well as increasing the kinetics of the mesenchymal-epithelial transition (MET) required for reprogramming. ${ }^{55,56}$ Only the use of miR$302 \mathrm{a} / \mathrm{b} / \mathrm{c} / \mathrm{d}$ and miR-367 is able to reprogram adult cells, and with greater efficiency, when compared to the Yamanaka method. ${ }^{57}$ Data demonstrate that miR302 in conjunction with Yamanaka factors inhibits NR2F2 (nuclear receptor subfamily 2, group F, member 2) and improves reprogramming efficiency through indirect positive regulation of Oct $4 .^{58}$

- miR-200b and -200c, miR-205: These promote MET via signaling of transforming growth factor $\beta$ (TGF- $\beta$ ) and, in conjunction with the Yamanaka factors, exclude the need for signaling of bone morphogenetic protein (BMP) during the initial reprogramming phase. ${ }^{59}$

- miR-93, miR-106: They suppress the expression of TGF- $\beta$ and $\mathrm{p} 21$, leading to MET and increased proliferation. ${ }^{60}$

- miR-135b: This is highly expressed during the reprogramming process, regulating the expression of TGF- $\beta$, IGFBP5 (insulin-like growth factor binding protein 5) and Wisp1 (inducible-signaling pathway protein 1), which are involved in the expression of extracellular matrix genes. ${ }^{61}$
MicroRNAs that are barriers to iPSC reprogramming

- miR Let-7 (cluster): This inhibits the Pou5f1/Oct4, Sox 2 , Nanog and Tcf3 targets - pluripotency factors - stabilizing a differentiated state. In addition, this miRNA inhibits the translation of CDK4, repressing the transition of the G1-S-phase. MiR Let-7 forms a negative feedback circuit, providing a molecular mechanism that facilitates the decision between self-renewal and differentiation of cells. ${ }^{50,62}$

- $\mathrm{miR}-34 \mathrm{a}, \mathrm{miR}-34 \mathrm{~b} / \mathrm{c}$ : miR-34a represses the expression of Nanog, Sox 2 and c-Myc. Taken in conjunction, miR-34a and miR-34b/c target p53 (tumor suppressor gene), holding an essential role in the containment of somatic reprogramming. ${ }^{63}$

These studies show that miRNAs can be important tools in the mediation of iPSC reprogramming without the need for the ectopic expression of pluripotency induction factors, including OSKM factors. The tables below present a summary of different approaches and their effects on iPSC reprogramming. Table 1 is related to changes in DNA methylation, Table 2 is related to modifications in histones and Table 3 is related to the use of miRNAs. In addition, Figure 1 presents these changes in summarized form.

\section{Clinical application of IPSCs}

The main discussion about the use of iPSC in regenerative medicine is related to their ability to transform into cancer cells. Incomplete reprogramming of iPSC may be associated with the emergence of various mutations.

In addition to the impact on iPSC reprogramming, OSKM factors are associated with the development of tumors. Oct4 is highly expressed in the cervical cancer cell line. Deletion of Sox2 is associated with regression of melanomas. The Klf4 and c-Myc factors regulate genes involved in cell growth and proliferation. ${ }^{64}$ However, over the last 10 years following the discovery of iPSC, this technology has undergone several changes, such as the use of episomal plasmids that are not integrated into the genome, diminishing the carcinogenic potential of these cells. ${ }^{65}$ Currently, several methods are used to develop iPSC lines, including the use of plasmids, transposons, adenovirus, Sendai virus, miRNA and chemical compounds, minimizing mutagenic factors. Given these advances, iPSC have been used in pre-clinical tests and clinical trials.

The first transplant of iPSC in humans occurred in Japan in the second half of 2014, in a 70-year-old patient with age-related macular degeneration (AMD). This pa- 
TABLE 1 Epigenetic DNA changes.

\begin{tabular}{|c|c|c|c|c|c|c|}
\hline Authors & Year & Species & Type of cell & Technology & Epigenetic changes & Results \\
\hline Mikkelsen et al. ${ }^{33}$ & 2008 & Mice & Fibroblasts & $\begin{array}{l}\text { 5-azacytidine } \\
(A Z A)\end{array}$ & $\begin{array}{l}\text { Inhibitor of DNA } \\
\text { methyltransferase }\end{array}$ & $\begin{array}{l}\text { Promotes the demethylation of } \\
\text { pluripotency genes }\end{array}$ \\
\hline Mikkelsen et al. ${ }^{33}$ & 2008 & Mice & Fibroblasts & shRNA/siRNA & $\begin{array}{l}\text { Reduced expression of } \\
\text { DNMT1 using siRNA/shRNA }\end{array}$ & $\begin{array}{l}\text { Demethylation and complete } \\
\text { reprogramming of cells }\end{array}$ \\
\hline Popp et al. ${ }^{28}$ & 2010 & Mice & Embryonic & AID & DNA demethylation & $\begin{array}{l}\text { Clears all standard } \\
\text { demethylation of the genome }\end{array}$ \\
\hline Doege et al. ${ }^{29}$ & 2012 & Mice & Fibroblasts & Tet2 & $\begin{array}{l}\text { Generation of } \\
5 \text {-hydroxymethylcytosine } \\
(5 \mathrm{hmC}) \text { through the } \\
\text { oxidation of } 5 \mathrm{mC}\end{array}$ & $\begin{array}{l}\text { Hydroxylation of pluripotency } \\
\text { sites (Nanog and Esrrb) favoring } \\
\text { a greater number of iPSCs }\end{array}$ \\
\hline Costa et al. ${ }^{30}$ & 2013 & Mice & Embryonic & Tet1/Tet2 & $\begin{array}{l}\text { Physical interaction with } \\
\text { Nanog }\end{array}$ & $\begin{array}{l}\text { Hydroxylation of pluripotency } \\
\text { sites (Oct4 and Esrrb) }\end{array}$ \\
\hline Gao et al. ${ }^{31}$ & 2013 & Mice & Fibroblasts & Tet1 & $\begin{array}{l}\text { DNA demethylation and } \\
\text { activation of Oct } 4\end{array}$ & $\begin{array}{l}\text { Better induction of } \\
\text { pluripotency }\end{array}$ \\
\hline
\end{tabular}

iPSCs: induced pluripotent stem cells.

\section{TABLE 2 Epigenetic changes in histones.}

\begin{tabular}{llllll} 
Authors & Year & Species & Type of cell & Technology & Epigenetic changes \\
\hline${\text { Huangfu et al. }{ }^{44}}^{2} 2008$ & Mice & Fibroblasts & VPA/TSA/SAHA & $\begin{array}{l}\text { Inhibitor of histone } \\
\text { deacetylation }\end{array}$ \\
\hline Shi et al. ${ }^{43}$ & 2008 & Mice & Fibroblasts & BIX-01294 & G9a methyltransferase \\
& & & & & inhibitor
\end{tabular}

\section{Results}

Prevents histone deacetylation, increasing reprogramming efficiency by more than 100X compared to OSKM

inhibitor Reduces histone $\mathrm{H} 3 \mathrm{~K} 9$ methylation, facilitating transcription. Improves reprogramming efficiency compared to Oct4 and KIf4

\begin{tabular}{|c|c|c|c|c|c|c|}
\hline Esteban et al. ${ }^{35}$ & 2010 & Humans & Fibroblasts & Vitamin C & $\begin{array}{l}\text { Nanog promoter, Oct4/ } \\
\text { Histone demethylation }\end{array}$ & $\begin{array}{l}\text { Decreases senescence during } \\
\text { reprogramming }\end{array}$ \\
\hline Liang et al. ${ }^{46}$ & 2010 & Mice & Fibroblasts & Sodium butyrate & $\begin{array}{l}\text { Histone deacetylase } \\
\text { (HDAC) inhibitor }\end{array}$ & $\begin{array}{l}\text { Facilitates reprogramming mediated by } \\
\text { c-Myc }\end{array}$ \\
\hline Liang et al. ${ }^{48}$ & 2012 & Mice & Fibroblasts & $\begin{array}{l}\text { Lentivirus increasing } \\
\text { the expression of } \\
\mathrm{Kdm} 2 \mathrm{~b}\end{array}$ & $\begin{array}{l}\text { Activation of genes in } \\
\text { the initial phase of } \\
\text { reprogramming }\end{array}$ & $\begin{array}{l}\text { Decreased H3K36me2 levels, } \\
\text { contributing to reprogramming }\end{array}$ \\
\hline Onder et al. ${ }^{47}$ & 2012 & Mice & Fibroblasts & epz004777 & $\begin{array}{l}\text { DOT1L inhibitor } \\
\text { (Histone } \\
\text { methyltransferase } \\
\text { specific for H3K79) }\end{array}$ & $\begin{array}{l}\text { With the reduction of DOT } 1 \mathrm{~L} \text {, a } \\
\text { reduction in the methylation of } \mathrm{H} 3 \mathrm{~K} 79 \\
\text { occurs, improving the reprogramming } \\
\text { by increasing transcription factors such } \\
\text { as Nanog and Lin } 28\end{array}$ \\
\hline Chen et al. ${ }^{45}$ & 2013 & Mice & Fibroblasts & Vitamin C & $\begin{array}{l}\text { Increases Kdm3 and } \\
\text { Kdm4 - Lysine-specific } \\
\text { demethylase }\end{array}$ & $\begin{array}{l}\text { Reduces } \mathrm{H} 3 \mathrm{~K} 9 \mathrm{me} 2 \text { and } \mathrm{H} 3 \mathrm{~K} 9 \mathrm{me} 3 \text {, } \\
\text { important early in the reprogramming } \\
\text { of iPSCs }\end{array}$ \\
\hline Hou et al. ${ }^{42}$ & 2013 & Mice & Fibroblasts & $\begin{array}{l}\text { 3-deazaneplanocin } \\
\text { A (Dznep) }\end{array}$ & $\begin{array}{l}\text { Histone } \\
\text { methyltransferase } \\
\text { inhibitor }\end{array}$ & $\begin{array}{l}\text { Better reprogramming occurs with } \\
\text { inhibition of histone methyltransferase } \\
\text { by preventing methylation in the } \\
\text { arginine and lysine residues of histones }\end{array}$ \\
\hline
\end{tabular}


TABLE 3 Epigenetic changes using microRNAs.

\begin{tabular}{|c|c|c|c|c|c|c|}
\hline Authors & Year & miRNA & Species & Type of cell & Mechanism of action & Results \\
\hline Judson et al. ${ }^{54}$ & 2009 & $290-295$ & Mice & Fibroblast & $\begin{array}{l}\text { Blocks p21, leading to } \\
\text { increased cell cycle proteins }\end{array}$ & $\begin{array}{l}\text { Promotes the G1-S phase transition } \\
\text { (proliferation), indirectly activating } \\
\text { pluripotency factors }\end{array}$ \\
\hline $\mathrm{Li}$ and $\mathrm{He}^{50}$ & 2012 & Let-7 & Mice & $\begin{array}{l}\text { Embryonic } \\
\text { stem cell }\end{array}$ & $\begin{array}{l}\text { Reduced CyclinD/Cdk4 } \\
\text { regulation }\end{array}$ & Blocks G1-S phase \\
\hline $\begin{array}{l}\text { Subramanyam et } \\
\text { al.; Lin et al. }{ }^{55,56}\end{array}$ & 2011 & $302-367$ & Mice & Fibroblast & Inhibits TGFII- $\beta$ & Promotes MET \\
\hline Choi et al. ${ }^{63}$ & 2011 & $\begin{array}{l}34 \mathrm{a} \text { and } \\
34 \mathrm{~b} / \mathrm{c}\end{array}$ & Mice & Fibroblast & $\begin{array}{l}\text { Reduced regulation of p21 } \\
\text { and p53 }\end{array}$ & Indirectly blocks pluripotency factors \\
\hline Li et al. ${ }^{61}$ & 2014 & $135 b$ & Mice & Fibroblast & $\begin{array}{l}\text { Reduced expression of } \\
\text { TGF- } \beta \text {, Igfbp } 5 \text {, and Wisp } 1\end{array}$ & Promotes MET \\
\hline Zare et al. ${ }^{49}$ & 2015 & $124-128$ & Humans & Fibroblast & $\begin{array}{l}\text { Regulate the development } \\
\text { of neurons }\end{array}$ & $\begin{array}{l}\text { Promotes the migration, maturation } \\
\text { and differentiation of neurons, } \\
\text { maintaining adequate gene expression } \\
\text { and repressing unwanted genes }\end{array}$ \\
\hline
\end{tabular}

MET: mesenchymal-epithelial transition.

thology affects around 700,000 people in Japan, and is the most common form of blindness in people aged over 60 , causing progressive loss of the retinal pigment epithelial monolayer. The transplant lasted around two hours and, according to the researchers, the patient did not suffer adverse effects, and there were an improvement in the morphology of the macula and neovascularization. ${ }^{66}$

This clinical trial was carried out by the group of Professor Takahashi, co-author of the manuscripts that won Professor Yamanaka the Nobel Prize in Medicine in 2012. However, in March 2015, clinical testing intended to treat six patients was suspended due to regulatory changes in regenerative medicine in Japan. ${ }^{67}$

Other clinical trials are currently underway to test the effectiveness of cellular therapy with iPSC in the treatment of AMD, Parkinson's disease, spinal cord injury, diabetes and myocardial infarction. ${ }^{68}$ Preliminary results have not yet been presented.

Maintenance of the epigenetic factors of the iPSC after reprogramming has also been used to understand the molecular pathways involved in the development of diseases, development of new drugs and personalized medicine. ${ }^{69}$ The first study conducted of this kind used a model of neuropathic disease. The authors reprogrammed fibroblasts from patients with Riley-Day syndrome and monitored in vitro splicing of the IKBKAP (mutation associated with the disorder). Furthermore, the researchers also evaluated candidate drugs for reversal of the splicing. The study of iPSC gains relevance in this case, due to the inability of accessing the tissues affected by Riley-Day syndrome. ${ }^{70}$ Other studies have been developed along this line, ${ }^{69}$ and are promising in the context of drug development. Figure 2 summarizes the use of iPSC.

\section{Conclusion}

Despite the improvement recently seen in iPSC reprogramming by up to 100 times, when compared to Yamanaka factors ${ }^{44}$ the yield remains relatively low and high costs. Another problem is the long period for full iPSC reprogramming and the high cells proliferation rates associated with a greater chance of developing cancer. ${ }^{71}$ Takahashi and Yamanaka suggest considering using iPSC with allogeneic transplantation in regenerative medicine, which would improve the effectiveness of the treatment of certain diseases such as spinal cord injury, which requires quick treatment without waiting for the time taken for reprogramming. ${ }^{11}$ Furthermore, there is a need for better understanding of how the reprogramming interventions influence the epigenetic memory of the reprogrammed cells. Despite advances in iPSC reprogramming, certain questions have emerged: 1 ) Is it possible to completely erase the somatic epigenetic memory by associating the different treatments mentioned?; 2) Could "forced" reprogramming cause long-term damage, such as the development of cancer or other diseases?; 3) Is it possible to replace embryonic stem cells with iPSC in regenerative medicine? In spite of the extraordinary progress achieved recently in the use of iPSC, the deepening of ongoing studies and realization of new studies are necessary in order to elucidate 


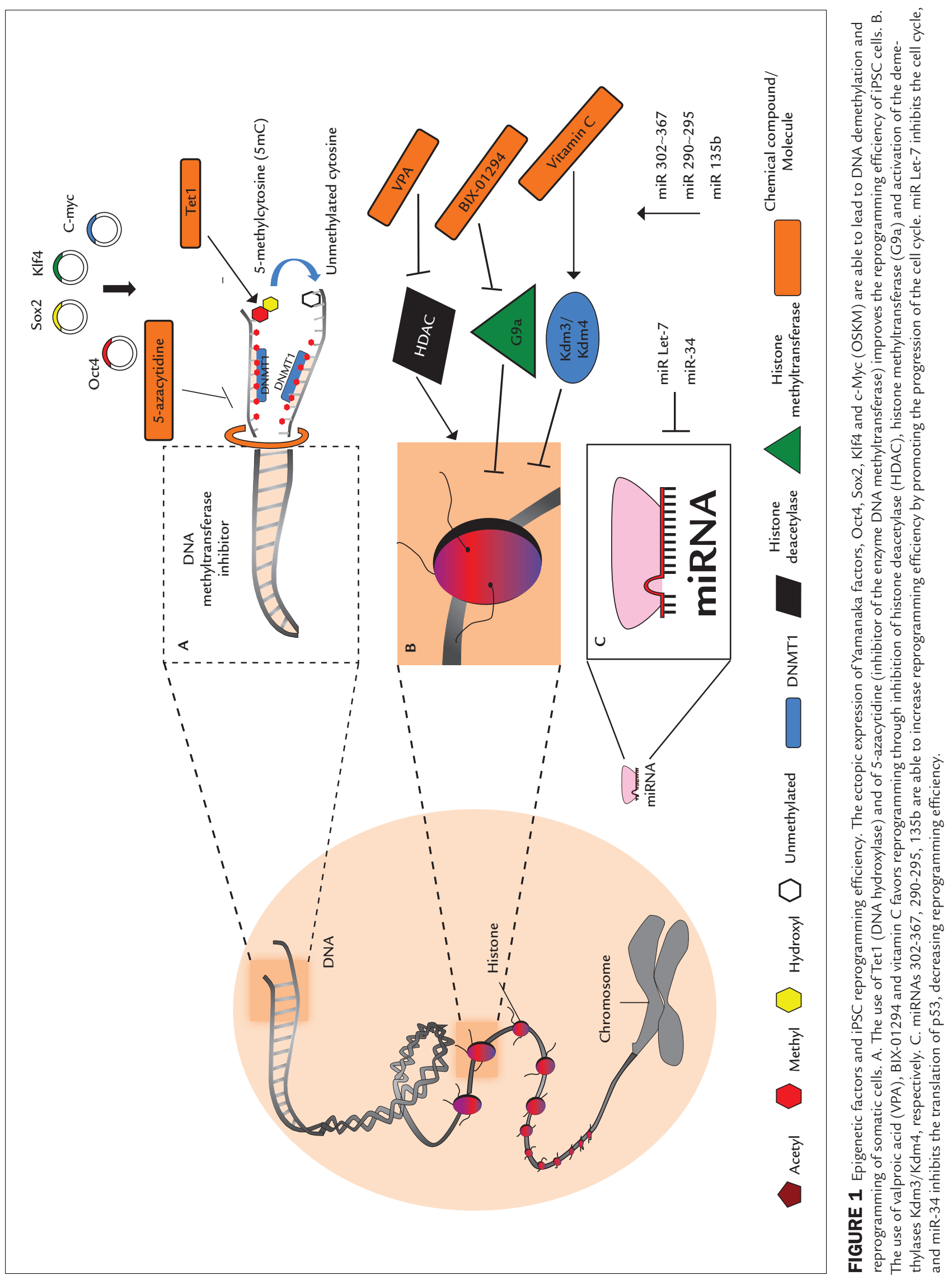




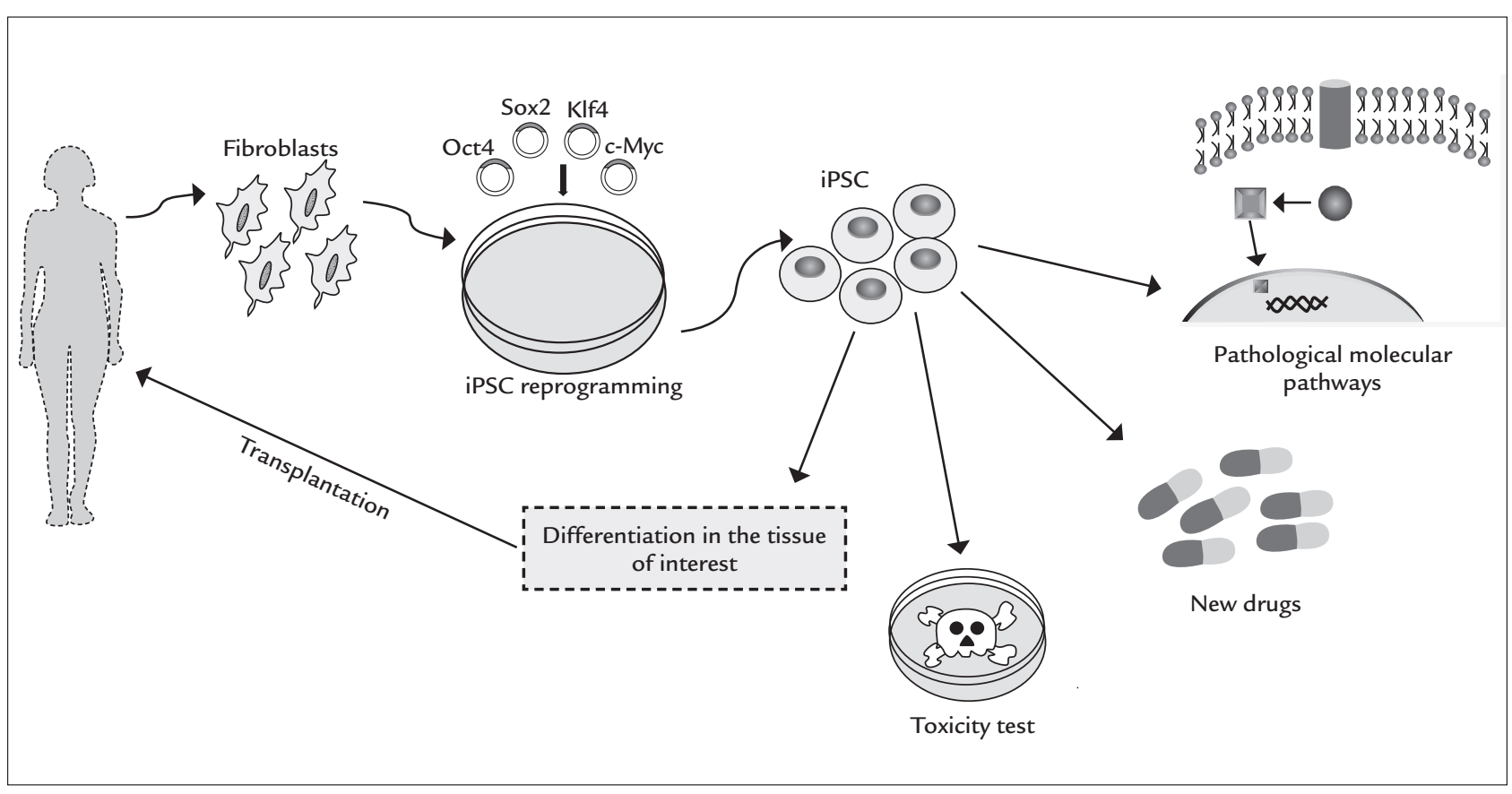

FIGURE 2 Somatic cells are reprogrammed into induced pluripotent stem cells (iPSCs). These cells are differentiated in the tissue of interest and transplanted in an attempt to reduce the damage caused by degenerative diseases. In addition, iPSCs are also being used in pre-clinical and clinical tests.

the mechanisms of the aforementioned changes, optimizing their application in regenerative medicine.

\section{Resumo}

Células-tronco de pluripotência induzida: papel da epigenética na reprogramação e sua aplicabilidade clínica

As células-tronco de pluripotência induzida (CTPI) ou do inglês induced pluripotent stem cells (iPSCs) são células somáticas reprogramadas para o estado embrionário por meio da expressão de fatores ectópicos de transcrição específicos, tornando-as um alvo promissor para a medicina regenerativa. Apesar das CTPI compartilharem características embrionárias, como pluripotência e capacidade de autorrenovação, elas possuem uma baixa eficiência de reprogramação, sendo a memória epigenética uma das principais barreiras nesse processo. A epigenética é caracterizada por alterações reversíveis e herdáveis no genoma funcional que não alteram a sequência de nucleotídeos do DNA. Dentre as diferentes modificações epigenéticas, destacam-se metilação de DNA, alterações em histonas e microRNA. Atualmente, sabe-se que o processo de reprogramação efetivo das CTPI envolve um completo remodelamento da memória epigenética somática existente, seguido pelo estabelecimento de uma "as- sinatura epigenética" que esteja de acordo com o novo tipo de célula a ser diferenciada. Modificações epigenéticas personalizadas são capazes de melhorar o rendimento e a efetividade das CTPI geradas, abrindo uma nova perspectiva para a terapia celular. Nesta revisão reunimos as principais informações sobre os fatores epigenéticos que afetam a reprogramação das CTPI, bem como seus benefícios na aplicação da terapia celular.

Palavras-chave: células-tronco de pluripotência induzida, medicina regenerativa, reprogramação celular, epigenética, histonas, microRNA.

\section{References}

1. Biehl JK, Russell B. Introduction to stem cell therapy. J Cardiovasc Nurs 2014; 24(2):98-103; quiz 104-5.

2. Lo B, Parham L. Ethical issues in stem cell research. Endocr Rev. 2009; 30(3):204-13.

3. Gurdon JB, Elsdale TR, Fischberg M. Sexually mature individuals of Xenopus laevis from the transplantation of single somatic nuclei. Nature. 1958; 182(4627):64-5.

4. Tachibana M, Amato P, Sparman M, Gutierrez NM, Tippner-Hedges R, Ma $\mathrm{H}$, et al. Human embryonic stem cells derived by somatic cell nuclear transfer. Cell. 2014; 153(6):1228-38.

5. Cowan C a, Atienza J, Melton DA, Eggan K. Nuclear reprogramming of somatic cells after fusion with human embryonic stem cells. Science. 2005; 309(5739):1369-73.

6. Takahashi K, Yamanaka S. Induction of pluripotent stem cells from mouse embryonic and adult fibroblast cultures by defined factors. Cell. 2006; 126(4):663-76 
7. Patel M, Yang S. Advances in reprogramming somatic cells to induced pluripotent stem cells. Stem Cell Rev. 2010; 6(3):367-80

8. Johnson MH, Cohen J. Reprogramming rewarded: the 2012 Nobel Prize for Physiology or Medicine awarded to John Gurdon and Shinya Yamanaka. Reprod Biomed Online. 2012; 25(6):549-50.

9. Lowry WE, Plath K. The many ways to make an iPS cell. Nat Biotechnol. 2008; 26(11):1246-8.

10. Yu J, Vodyanik MA, Smuga-Otto K, Antosiewicz-Bourget J, Frane JL, Tian $\mathrm{S}$, et al. Induced pluripotent stem cell lines derived from human somatic cells. Science. 2007; 318(5858):1917-20.

11. Takahashi K, Yamanaka S. Induced pluripotent stem cells in medicine and biology. Development. 2013; 140(12):2457-61.

12. Apostolou E, Hochedlinger K. Chromatin dynamics during cellular reprogramming. Nature. 2013; 502(7472):462-71.

13. Chin MH, Mason MJ, Xie W, Volinia S, Singer M, Peterson C, et al. Induced pluripotent stem cells and embryonic stem cells are distinguished by gene expression signatures. Cell Stem Cell. 2009; 5(1):111-23.

14. Kim K, Doi A, Wen B, Ng K, Zhao R, Cahan P, et al. Epigenetic memory in induced pluripotent stem cells. Nature. 2010; 467(7313):285-90.

15. Polo JJM, Liu S, Figueroa MME, Kulalert W, Eminli S, Tan KY, et al. Cell type of origin influences the molecular and functional properties of mouse induced pluripotent stem cells. Nat Biotechnol. 2010; 28(8):848-55 .

16. Nashun B, Hill PWS, Hajkova P. Reprogramming of cell fate: epigenetic memory and the erasure of memories past. EMBO J. 2015; 34(10):1296-308

17. Waddington $\mathrm{CH}$. The epigenotype. 1942. Int J Epidemiol. 2012; 41(1):10-3.

18. Haig D. The (dual) origin of epigenetics. Cold Spring Harb Symp Quant Biol. 2004; 69:67-70.

19. Kim SY, Morales CR, Gillette TG, Hill JA. Epigenetic regulation in heart failure. Curr Opin Cardiol. 2016;31(3):255-65.

20. Abdolmaleky HM, Zhou J-R, Thiagalingam $S$. An update on the epigenetics of psychotic diseases and autism. Epigenomics. 2015; 7(3):427-49.

21. Faroogi AA, Tang JY, Li RN, Ismail M, Chang YT, Shu CW, et al. Epigenetic mechanisms in cancer: push and pull between kneaded erasers and fate writers. Int J Nanomedicine. 2015; 10:3183-91.

22. Coppedè $F$. The potential of epigenetic therapies in neurodegenerative diseases. Front Genet. 2014; 5:220.

23. Gładych M, Andrzejewska A, Oleksiewicz U, Estécio MRH. Epigenetic mechanisms of induced pluripotency. Contemp Oncol (Pozn). 2015 19(1A):A30-8.

24. Djuric U, Ellis J. Epigenetics of induced pluripotency, the seven-headed dragon. Stem Cell Res Ther. 2010; 1(1):3.

25. Liang G, Zhang Y. Embryonic stem cell and induced pluripotent stem cell an epigenetic perspective. Cell Res. 2013; 23(1):49-69.

26. Hackett JA, Surani MA. DNA methylation dynamics during the mammalian life cycle. Philos Trans R Soc Lond B Biol Sci. 2013; 368(1609):20110328.

27. Nishino K, Toyoda M, Yamazaki-Inoue M, Fukawatase Y, Chikazawa E, Sakaguchi $\mathrm{H}$, et al. DNA methylation dynamics in human induced pluripotent stem cells over time. PLoS Genet. 2011; 7(5):5-8.

28. Popp C, Dean W, Feng S, Cokus SJ, Andrews S, Pellegrini M, et al. Genomewide erasure of DNA methylation in mouse primordial germ cells is affected by AID deficiency. Nature. 2010; 463(7284):1101-5.

29. Doege CA, Inoue K, Yamashita T, Rhee DB, Travis S, Fujita R, et al. Early-stage epigenetic modification during somatic cell reprogramming by Parp 1 and Tet2. Nature. 2012; 488(7413):652-5.

30. Costa Y, Ding J, Theunissen TW, Faiola F, Hore TA, Shliaha PV, et al. NANOG-dependent function of TET1 and TET2 in establishment of pluripotency. Nature. 2013; 495(7441):370-4

31. Gao Y, Chen J, Li K, Wu T, Huang B, Liu W, et al. Replacement of Oct 4 by Tet 1 during iPSC induction reveals an important role of DNA methylation and hydroxymethylation in reprogramming. Cell Stem Cell. 2013; 12(4):453-69.

32. Watanabe A, Yamada Y, Yamanaka S. Epigenetic regulation in pluripotent stem cells: a key to breaking the epigenetic barrier. Phil Trans R Soc. 2013; 368:(1609):20120292.

33. Mikkelsen TS, Hanna J, Zhang X, Ku M, Wernig M, Schorderet P, et al. Dissecting direct reprogramming through integrative genomic analysis. Nature. 2008; 454(7200):49-55

34. Wang T, Chen K, Zeng X, Yang J, Wu Y, Shi X, et al. The histone demethylases Jhdm $1 \mathrm{a} / 1 \mathrm{~b}$ enhance somatic cell reprogramming in a vitamin-C-dependent manner. Cell Stem Cell. 2011; 9(6):575-87.

35. Esteban MA, Wang T, Qin B, Yang J, Qin D, Cai J, et al. Vitamin C enhances the generation of mouse and human induced pluripotent stem cells. Cell Stem Cell. 2010; 6(1):71-9.
36. Bagci H, Fisher AG. DNA demethylation in pluripotency and reprogramming: the role of Tet proteins and cell division. Cell Stem Cell. 2013; 13(3):265-9.

37. Sadakierska-Chudy A, Filip M. A comprehensive view of the epigenetic landscape. Part II: Histone post-translational modification, nucleosome level, and chromatin regulation by ncRNAs. Neurotox Res. 2014; 27(2):172-97.

38. Eissenberg JC, Shilatifard A. Histone $\mathrm{H} 3$ lysine 4 (H3K4) methylation in development and differentiation. Dev Biol. 2010; 339(2):240-9.

39. Becker JS, Nicetto D, Zaret KS. H3K9me3-dependent heterochromatin barrier to cell fate changes. Trends Genet. 2016; 32(1):29-41.

40. Lin T, Wu S. Reprogramming with small molecules instead of exogenous transcription factors. Stem Cells Int. 2015; 2015:794632.

41. Rais Y, Zviran A, Geula S, Gafni O, Chomsky E, Viukov S, et al. Deterministic direct reprogramming of somatic cells to pluripotency. Nature. 2013; 502(7469):65-70.

42. Hou P, Li Y, Zhang X, Liu C, Guan J, Li H, et al. Pluripotent stem cells induced from mouse somatic cells by small-molecule compounds. Science. 2013; 341(6146):651-4

43. Shi Y, Desponts C, Do JT, Hahm HS, Schöler HR, Ding S. Induction of pluripotent stem cells from mouse embryonic fibroblasts by Oct 4 and Klf4 with small-molecule compounds. Cell Stem Cell. 2008; 3(5):568-74.

44. Huangfu D, Maehr R, Guo W, Eijkelenboom A, Snitow M, Chen AE, et al. Induction of pluripotent stem cells by defined factors is greatly improved by small-molecule compounds. Nat Biotechnol. 2008; 26(7):795-7.

45. Chen J, Liu H, Liu J, Qi J, Wei B, Yang J, et al. H3K9 methylation is a barrier during somatic cell reprogramming into iPSCs. Nat Genet. 2013; 45(1):34-42.

46. Liang G, Taranova O, Xia K, Zhang Y. Butyrate promotes induced pluripotent stem cell generation. J Biol Chem. 2010;285(33):25516-21.

47. Onder TT, Kara N, Cherry A, Sinha AU, Zhu N, Bernt KM, et al. Chromatin-modifying enzymes as modulators of reprogramming. Nature. 2012; 483(7391):598-602

48. Liang G, He J, Zhang Y. Kdm2b promotes induced pluripotent stem cell generation by facilitating gene activation early in reprogramming. Nat Cell Biol. 2012; 14(5):457-66

49. Zare M, Soleimani M, Akbarzadeh A, Bakhshandeh B, Aghaee-Bakhtiari SH, Zarghami N. A novel protocol to differentiate induced pluripotent stem cells by neuronal microRNAs to provide a suitable cellular model. Chem Biol Drug Des. 2015; 86(2):232-8.

50. Li MA, He L. microRNAs as novel regulators of stem cell pluripotency and somatic cell reprogramming. Bioessays. 2012; 34(8):670-80.

51. Wang Y, Medvid R, Melton C, Jaenisch R, Blelloch R. DGCR8 is essential for microRNA biogenesis and silencing of embryonic stem cell self-renewal. Nat Genet. 2007; 39(3):380-5

52. Wang Y, Baskerville S, Shenoy A, Babiarz JE, Baehner L, Blelloch R. Embryonic stem cell-specific microRNAs regulate the G1-S transition and promote rapid proliferation. Nat Genet. 2008; 40(12):1478-83.

53. He L, Hannon GJ. MicroRNAs: small RNAs with a big role in gene regulation. Nat Rev Genet. 2004; 5(7):522-31.

54. Judson RL, Babiarz JE, Venere M, Blelloch R. Embryonic stem cell-specific microRNAs promote induced pluripotency. Nat Biotechnol. 2009; 27(5):459-61.

55. Subramanyam D, Lamouille S, Judson RL, Liu JY, Bucay N, Derynck R, et al. Multiple targets of miR-302 and miR-372 promote reprogramming of human fibroblasts to induced pluripotent stem cells. Nat Biotechnol. 2011; 29(5):443-8.

56. Lin SL, Chang DC, Lin CH, Ying SY, Leu D, Wu DTS. Regulation of somatic cell reprogramming through inducible mir-302 expression. Nucleic Acids Res. 2011; 39(3):1054-65.

57. Anokye-Danso F, Trivedi CM, Juhr D, Gupta M, Cui Z, Tian Y, et al. Highly efficient miRNA-mediated reprogramming of mouse and human somatic cells to pluripotency. Cell Stem Cell. 2011; 8(4):376-88.

58. Hu S, Wilson KD, Ghosh Z, Han L, Wang Y, Lan F, et al. MicroRNA-302 increases reprogramming efficiency via repression of NR2F2. Stem Cells. 2013; 31(2):259-68.

59. Samavarchi-Tehrani P, Golipour A, David L, Sung HK, Beyer TA, Datti A, et al. Functional genomics reveals a BMP-driven mesenchymal-to-epithelial transition in the initiation of somatic cell reprogramming. Cell Stem Cell. 2010; 7(1):64-77

60. Li Z, Yang C, Nakashima K, Rana TM. Small RNA-mediated regulation of iPS cell generation. EMBO J. 2011; 30(5):823-34.

61. Li Z, Dang J, Chang K, Rana TM. MicroRNA-mediated regulation of extracellular matrix formation modulates somatic cell reprogramming. RNA 2014; 20(12):1900-15 
62. Zhong X, Li N, Liang S, Huang Q, Coukos G, Zhang L. Identification of microRNAs regulating reprogramming factor LIN28 in embryonic stem cells and cancer cells. J Biol Chem. 2010; 285(53):41961-71.

63. Choi YJ, Lin C, Ho JJ, He X, Okada N, Bu P, et al. miR-34 miRNAs provide a barrier for somatic cell reprogramming. Nat Cell Biol. 2011;13(11):1353-60.

64. Curry EL, Moad M, Robson CN, Heer R. Using induced pluripotent stem cells as a tool for modelling carcinogenesis. World J Stem Cells. 2015; 7(2):461-9.

65. Takahashi K, Yamanaka S. A decade of transcription factor-mediated reprogramming to pluripotency. Nat Rev Mol Cell Biol. 2016; 17(3):183-93.

66. First iPS cell transplant patient makes progress one year on. The Japan Times [internet]. 2015 [cited 23 May 2016]. Available from: http://www. japantimes.co.jp/news/2015/10/02/national/science-health/first-ips-celltransplant-patient-makes-progress-one-year\#.WJxP59JVikq
67. Garber K. RIKEN suspends first clinical trial involving induced pluripotent stem cells. Nat Biotechnol. 2015; 33(9):890-1.

68. Trounson A, DeWitt ND. Pluripotent stem cells progressing to the clinic. Nat Rev Mol Cell Biol. 2016; 17(3):194-200.

69. Avior Y, Sagi I, Benvenisty N. Pluripotent stem cells in disease modelling and drug discovery. Nat Rev Mol Cell Biol. 2016; 17(3):170-82.

70. Lee G, Papapetrou EP, Kim H, Chambers SM, Tomishima MJ, Fasano CA, et al. Modelling pathogenesis and treatment of familial dysautonomia using patient-specific iPSCs. Nature. 2009; 461(7262):402-6.

71. Wasik AM, Grabarek J, Pantovic A, Cieślar-Pobuda A, Asgari HR, BundgaardNielsen C, et al. Reprogramming and carcinogenesis - parallels and distinctions. Int Rev Cell Mol Biol. 2014; 308:167-203. 